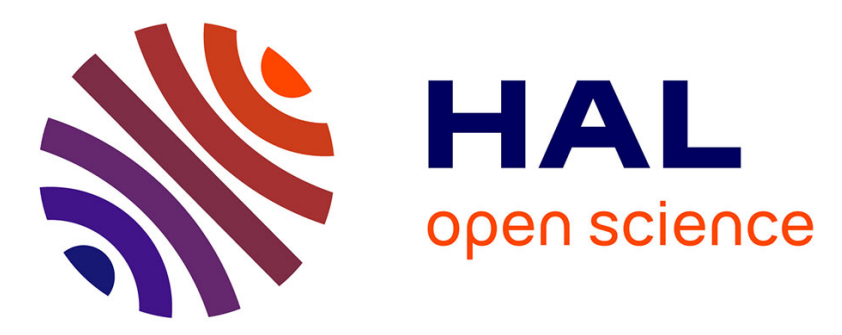

\title{
Novel color-tunable Gd2O2CN2:Tb3+, Eu3+ phosphors: Characterization and photoluminescence properties
}

Shuanglong Yuan, Luting Wang, Yunxia Yang, François Cheviré, Franck Tessier, Guorong Chen

\section{- To cite this version:}

Shuanglong Yuan, Luting Wang, Yunxia Yang, François Cheviré, Franck Tessier, et al.. Novel colortunable Gd2O2CN2:Tb3+, Eu3+ phosphors: Characterization and photoluminescence properties. Ceramics International, 2016, 42 (10), pp.12508-12511. 10.1016/j.ceramint.2016.04.059 . hal-01302508

HAL Id: hal-01302508

https://hal-univ-rennes1.archives-ouvertes.fr/hal-01302508

Submitted on 8 Sep 2016

HAL is a multi-disciplinary open access archive for the deposit and dissemination of scientific research documents, whether they are published or not. The documents may come from teaching and research institutions in France or abroad, or from public or private research centers.
L'archive ouverte pluridisciplinaire $\mathbf{H A L}$, est destinée au dépôt et à la diffusion de documents scientifiques de niveau recherche, publiés ou non, émanant des établissements d'enseignement et de recherche français ou étrangers, des laboratoires publics ou privés. 


\title{
ACCEPTED MANUSCRIPT
}

\section{Novel color-tunable $\mathrm{Gd}_{2} \mathrm{O}_{2} \mathrm{CN}_{2}: \mathrm{Tb}^{3+}, \mathrm{Eu}^{3+}$ phosphors: Characterization and}

\section{photoluminescence properties}

Shuanglong Yuan ${ }^{1 *}$, Luting Wang ${ }^{1}$, Yunxia Yang ${ }^{1}$, Francois Cheviré2 ${ }^{2}$, Franck Tessier ${ }^{2}$, Guorong

$$
\text { Chen }^{1}
$$

${ }^{1}$ Key Laboratory for Ultrafine Materials of Ministry of Education, School of Materials Science and Engineering, East China University of Science and Technology, Shanghai 200237, China ${ }^{2}$ Institut des Sciences Chimiques de Rennes (UMR CNRS 6226), équipe Verres et Céramiques, Université de Rennes 1, F-35042 Rennes cedex, France

*Corresponding author : Shuanglong@ecust.edu.cn

\begin{abstract}
In this paper, color-tunable $\mathrm{Gd}_{2} \mathrm{O}_{2} \mathrm{CN}_{2}: \mathrm{Tb}^{3+}, \mathrm{Eu}^{3+}$ phosphors were obtained by co-doping $\mathrm{Eu}^{3+}$ and $\mathrm{Tb}^{3+}$ ions into $\mathrm{Gd}_{2} \mathrm{O}_{2} \mathrm{CN}_{2}$ host and singly varying the $\mathrm{Eu}^{3+}$ doping concentration. The characteristics of the crystal structure, photoluminescence lifetime and photoluminescence of $\mathrm{Tb}^{3+}, \mathrm{Eu}^{3+}$ single-doped and $\mathrm{Tb}^{3+}$ and $\mathrm{Eu}^{3+}$ co-doped $\mathrm{Gd}_{2} \mathrm{O}_{2} \mathrm{CN}_{2}$, were carefully investigated by XRD, FTIR, PL decay curves and photoluminescence (PL). The results indicated that $\mathrm{Tb}^{3+}$ single-doped $\mathrm{Gd}_{2} \mathrm{O}_{2} \mathrm{CN}_{2}$ phosphor show a green emission, and by increasing $\mathrm{Eu}^{3+}$ content, $\mathrm{Gd}_{2} \mathrm{O}_{2} \mathrm{CN}_{2}: \mathrm{Tb}^{3+}, \mathrm{Eu}^{3+}$ phosphors emit green to orange and then to red light under the excitation of 379nm.
\end{abstract}

Keywords: Photoluminescence; $\mathrm{Gd}_{2} \mathrm{O}_{2} \mathrm{CN}_{2}: \mathrm{Tb}^{3+}$, Eu ${ }^{3+}$; color-tunable phosphors

\section{Introduction}

During the past few years, rare earth oxycyanamide compounds as host materials have received much attention due to their outstanding luminescence properties when doped with rare-earth ions[1-3]. The structures of $\mathrm{RE}_{2} \mathrm{O}_{2} \mathrm{CN}_{2}$ and $\mathrm{RE}_{2} \mathrm{O}_{2} \mathrm{~S}$ are closely related [4] and previous work has 


\section{ACCEPTED MANUSCRIPT}

shown that the luminescence properties of $\mathrm{RE}_{2} \mathrm{O}_{2} \mathrm{~S}: \mathrm{Eu}^{3+}$ (RE=Gd and $\mathrm{Y}$ ) and $\mathrm{RE}_{2} \mathrm{O}_{2} \mathrm{CN}_{2}: \mathrm{Eu}^{3+}$ (RE=Gd and $\mathrm{Y}$ ) are quite similar [5, 6]. Therefore, such oxycyanamide compounds are considered to be efficient host candidates for rare-earth activators ions such as $\mathrm{Eu}^{3+}$ and $\mathrm{Tb}^{3+}$ for instance. $\mathrm{Eu}^{3+}$ is considered as an important activator ion with red emission corresponding to the transition of ${ }^{5} \mathrm{D}_{0}{ }^{7} \mathrm{~F}_{\mathrm{J}}(\mathrm{J}=1-6)$ [7]. The emission of $\mathrm{Tb}^{3+}$ is due to the transition between the emitting states of ${ }^{5} \mathrm{D}_{\mathrm{j}}$ and the excited states of ${ }^{7} \mathrm{~F}_{\mathrm{j}}$, and the main intense green emission is attributed to the transition of ${ }^{5} \mathrm{D}_{4^{-}}{ }^{7} \mathrm{~F}_{5}$ which is located at ca. $543 \mathrm{~nm}[8]$.

In the previous study, we have reported the strong red emission of $\mathrm{Eu}^{3+}$ doped $\mathrm{Gd}_{2} \mathrm{O}_{2} \mathrm{CN}_{2}$ phosphors [9]. In this work, we report a new color tunable phosphor $\mathrm{Gd}_{2} \mathrm{O}_{2} \mathrm{CN}_{2}: \mathrm{Tb}^{3+}$, Eu ${ }^{3+}$. A series of $\mathrm{Tb}^{3+}, \mathrm{Eu}^{3+}$ singly-doped and $\mathrm{Tb}^{3+}-\mathrm{Eu}^{3+}$ co-doped phosphors were successfully prepared by classical solid state reaction at low firing temperature $\left(750{ }^{\circ} \mathrm{C}\right)$. The emitting color of $\mathrm{Gd}_{2} \mathrm{O}_{2} \mathrm{CN}_{2}: \mathrm{Tb}^{3+}, \mathrm{Eu}^{3+}$ phosphors can be tuned from green to orange and then to red by singly varying the doping concentration of $\mathrm{Eu}^{3+}$. The mechanism of energy transfer between $\mathrm{Tb}^{3+}$ and $\mathrm{Eu}^{3+}$ was investigated, and the results show that $\mathrm{Eu}^{3+} / \mathrm{Tb}^{3+}$ co-doped $\mathrm{Gd}_{2} \mathrm{O}_{2} \mathrm{CN}_{2}$ phosphors could serve as potential phosphors for NUV LEDs.

\section{Experimental}

Powder samples with the general formula $\mathrm{Gd}_{2-\mathrm{x}} \mathrm{Tb}_{\mathrm{x}} \mathrm{O}_{2} \mathrm{CN}_{2}$ [x=0.03(T-1), 0.05(T-2), 0.07(T-3), 0.12(T-4), 0.15(T-5) and 0.20 (T-6)], $\mathrm{Gd}_{1.90} \mathrm{Eu}_{0.1} \mathrm{O}_{2} \mathrm{CN}_{2}$ (GOCN-4) and $\mathrm{Gd}_{1.85-\mathrm{y}} \mathrm{Tb}_{0.15} \mathrm{Eu}_{\mathrm{y}} \mathrm{O}_{2} \mathrm{CN}_{2}$ [y=0.02(ET-1), 0.04(ET-2), 0.06(ET-3), 0.08(ET-4), 0.10(ET-5), 0.15(ET-6) were prepared by solid state reaction. High purity $\mathrm{GdF}_{3}(99.99 \%), \mathrm{Eu}_{2} \mathrm{O}_{3}$ (99.99\%), $\mathrm{Tb}_{4} \mathrm{O}_{7}(99.99 \%), \mathrm{Li}_{2} \mathrm{CO}_{3}$ (99.99\%), and active carbon (CARBIO 12 SA—ref: C1220 G 90) as the raw materials were thoroughly mixed and fired at $600{ }^{\circ} \mathrm{C}$ for $9 \mathrm{~h}$, then $750{ }^{\circ} \mathrm{C}$ for $12 \mathrm{~h}$ under $\mathrm{NH}_{3}$ atmosphere. The 


\section{ACCEPTED MANUSCRIPT}

detailed synthesis routes can be found in literature [9].

Powder X-ray diffraction (XRD) data were recorded using a Bruker AXS D8 Advance diffractometer (Voltage $50 \mathrm{kV}$, current $40 \mathrm{~mA}$, Cu-Ka). Photoluminescence (PL) and photoluminescence excitation (PLE) spectra were measured by a Fluorolog-3-P UV-vis-NIR fluorescence spectrophotometer (Jobin Yvon, longjumeau, France) with a $450 \mathrm{~W}$ Xenon lamp as the excitation source. The decay curves of $\mathrm{Tb}^{3+}$ emission was performed by FLSP920 (Edinburgh Instruments). The FTIR spectrum was measured in transmission mode using a $\mathrm{KBr}$ standard (Bruker, Model vector 22). The color chromaticity coordinates were obtained according to Commission Internationale de I'Eclairage (CIE) using Radiant Imaging color calculator software.

\section{Results and discussion}

As shown in Figure 1, the XRD patterns of the $\mathrm{Tb}^{3+}$ and/or $\mathrm{Eu}^{3+}$ activated $\mathrm{Gd}_{2} \mathrm{O}_{2} \mathrm{CN}_{2}$ samples can be readily indexed as a trigonal phase and identified as $\mathrm{Gd}_{2} \mathrm{O}_{2} \mathrm{CN}_{2}$ with the space group P-3m1 according to the JCPSQ database(PDF\#49-1169). Considering the similar coordinated environment, electronegativity and ionic radii of $\mathrm{Gd}^{3+}(\mathrm{r}=0.100 \mathrm{~nm}, \mathrm{CN}=7), \mathrm{Tb}^{3+}(\mathrm{r}=0.098 \mathrm{~nm}$, $\mathrm{CN}=7)$ and $\mathrm{Eu}^{3+}(\mathrm{r}=0.101 \mathrm{~nm}, \mathrm{CN}=7)$ ions, doping $\mathrm{Tb}^{3+}$ and $\mathrm{Eu}^{3+}$ does not result in any phase transformation and only has minor influence to the crystal structure.

Figure 2 shows the IR spectra of GOCN-4, ET-5 and T-5. IR spectra for ET-5 and T-5 both have the intense peaks at 2080 and $652 \mathrm{~cm}^{-1}$. In our previous study we reported that the typical absorption peaks in the vicinity of 2010 and $652 \mathrm{~cm}^{-1}$ in the GOCN-4 were respectively assigned to the $v_{2}$ (bending vibration) and $v_{3}$ (asymmetric stretching vibration) modes of the $\mathrm{CN}_{2}{ }^{2-}$ ion [9]. Hence, the IR spectra also indicate that $\mathrm{CN}_{2}{ }^{2-}$ ions contained in $\mathrm{Eu}^{3+}, \mathrm{Tb}^{3+}$ single-doped and $\mathrm{Eu}^{3+}-\mathrm{Tb}^{3+}$ co-doped $\mathrm{Gd}_{2} \mathrm{O}_{2} \mathrm{CN}_{2}$ samples. 


\section{ACCEPTED MANUSCRIPT}

Figure 3 illustrates the excitation (monitored at $543 \mathrm{~nm}$ ) and emission (excited by 280, 313 and $365 \mathrm{~nm}$ ) spectra of the T-5 sample (7.5 at. \% $\mathrm{Tb}^{3+}$ ). The excitation spectrum (Fig. 3a) exhibits a broad and intense band in the range from 250 to $300 \mathrm{~nm}$ with a peak at around $280 \mathrm{~nm}$. This broad band is attributed to $4 \mathrm{f}^{8}-4 \mathrm{f}^{7} 5 \mathrm{~d}^{1}$ transitions of $\mathrm{Tb}^{3+}$ ions. The other excitation bands at longer wavelengths, are located at $307 \mathrm{~nm}\left({ }^{5} \mathrm{H}_{5} \rightarrow{ }^{7} \mathrm{~F}_{6}\right), 313 \mathrm{~nm}\left({ }^{5} \mathrm{H}_{5} \rightarrow{ }^{7} \mathrm{~F}_{5}\right)$ and $350-380 \mathrm{~nm}$ ( transitions from ${ }^{7} \mathrm{~F}_{4},{ }^{7} \mathrm{~F}_{3}$ to ${ }^{5} \mathrm{H}_{7},{ }^{5} \mathrm{D}_{0},{ }^{5} \mathrm{D}_{1}$ ).The emission spectra of $\mathrm{T}-5$ (Fig. 3b) at different excitation wavelengths are very similar both in shape and relative intensities. The strongest peak split into two at 543 and $550 \mathrm{~nm}$ corresponds to the ${ }^{5} \mathrm{D}_{4} \rightarrow{ }^{7} \mathrm{~F}_{5}$ transition, while the peaks at 487 and $495 \mathrm{~nm}$, 587nm, and $622 \mathrm{~nm}$ respectively originate from the ${ }^{5} \mathrm{D}_{4} \rightarrow{ }^{7} \mathrm{~F}_{6},{ }^{5} \mathrm{D}_{4} \rightarrow{ }^{7} \mathrm{~F}_{4}$ and ${ }^{5} \mathrm{D}_{4} \rightarrow{ }^{7} \mathrm{~F}_{3}$ transitions of $\mathrm{Tb}^{3+}$ ions.

The excitation (monitored at 543nm) and emission (monitored at 280nm) spectra of $\mathrm{Gd}_{2-\mathrm{x}} \mathrm{Tb}_{\mathrm{x}} \mathrm{O}_{2} \mathrm{CN}_{2}$ with varying $\mathrm{Tb}^{3+}$ concentrations ( $\mathrm{x}=0.03,0.05,0.07,0.12,0.15$ and 0.20 ) are shown in Fig. 4. With the increase of doped $\mathrm{Tb}^{3+}$ ions concentration, the excitation and the emission intensity increases gradually ranging from 1.5 to 7.5 at. \% and decreases from 7.5 to 10 at. \%, which is in accordance with $\mathrm{Eu}^{3+}$ doped $\mathrm{Gd}_{2} \mathrm{O}_{2} \mathrm{CN}_{2}$ in previous work [9]. Considering the mechanism of energy transfer in phosphors, the concentration quenching can be explained in more details by the critical distance $\left(\mathrm{R}_{\mathrm{c}}\right)$ between $\mathrm{Tb}^{3+}$ ions which can be calculated by Eq. (1) [10]:

$$
R_{c}=2 \times\left(3 V / 4 \pi X_{c} N\right)^{1 / 3}
$$

Where $\mathrm{V}\left(101.9 \AA^{3}\right)$ is the volume of the unit cell, $\mathrm{X}_{\mathrm{c}}(0.075)$ is the critical concentration of $\mathrm{Tb}^{3+}$ ions and $\mathrm{N}(2)$ is the number of lattice sites in the unit cells that can be occupied by $\mathrm{Tb}^{3+}$ ions. Therefore, $\mathrm{R}_{\mathrm{c}}$ between $\mathrm{Tb}^{3+}$ ions is calculated to be $10.907 \AA$.

PL and PLE spectra of singly-doped $\mathrm{Eu}^{3+}$ (GOCN-4, 5 at. \%) or $\mathrm{Tb}^{3+}$ (T-5, 7.5 at. \%) and 
$\mathrm{Eu}^{3+} / \mathrm{Tb}^{3+}$ (ET-1, 1at. \%/ 7.5 at. \%) co-doped $\mathrm{Gd}_{2} \mathrm{O}_{2} \mathrm{CN}_{2}$ phosphors are presented in Fig. 5. The excitation spectrum of GOCN-4 exhibits a broad and intense band in the range from 250 to 350 $\mathrm{nm}$ with a peak at around $300 \mathrm{~nm}$, which is attributed to the ligand-to-metal charge transfer between $\mathrm{O}^{2-}$ and $\mathrm{Eu}^{3+}$. The weak excitation bands at longer wavelength corresponding to the $4 \mathrm{f}-4 \mathrm{f}$ transitions of $\mathrm{Eu}^{3+}$ are located at 379nm $\left({ }^{7} \mathrm{~F}_{0} \rightarrow{ }^{5} \mathrm{G}_{2}\right)$, 395nm $\left({ }^{7} \mathrm{~F}_{0} \rightarrow{ }^{5} \mathrm{~L}_{6}\right)$, 467nm $\left({ }^{7} \mathrm{~F}_{0} \rightarrow{ }^{5} \mathrm{D}_{2}\right)$. Upon excitation at 300nm, the emission spectrum shows two strong peaks at 614 and $626 \mathrm{~nm}$ which originate from the ${ }^{5} \mathrm{D}_{0} \rightarrow{ }^{7} \mathrm{~F}_{2}$ transition of $\mathrm{Eu}^{3+}$. Fig. 5 (b) shows the excitation and emission spectra of T-5, an intensive broad excitation band with the maximum at 280nm and other peaks at 313 and $379 \mathrm{~nm}$ are observed. Upon the excitation at 280nm, the emission spectrum shows a strong peak at $543 \mathrm{~nm}$ which is attributed to the transition ${ }^{5} \mathrm{D}_{4}{ }^{7} \mathrm{~F}_{5}$ of $\mathrm{Tb}^{3+}$. Fig. 5 (c) shows the excitation spectra of ET-1 monitored at 626 and 543nm, the excitation band at around 379nm can be observed in both excitation spectra. The emission spectrum of ET-1 shows typical peaks at $543 \mathrm{~nm}$ that originated from transition ${ }^{5} \mathrm{D}_{4}{ }^{7} \mathrm{~F}_{5}$ of $\mathrm{Tb}^{3+}$ and at 614 and $626 \mathrm{~nm}$ from transition ${ }^{5} \mathrm{D}_{0} \rightarrow{ }^{7} \mathrm{~F}_{2}$ of $\mathrm{Eu}^{3+}$.

The emission spectra of $\mathrm{Gd}_{1.85-\mathrm{y}} \mathrm{Tb}_{0.15} \mathrm{Eu}_{\mathrm{y}} \mathrm{O}_{2} \mathrm{CN}_{2}(0 \leq \mathrm{y} \leq 0.15)$ are illustrated in Fig. 6. All samples exhibit two prominent peaks peaking at 543 and 626nm under 379nm excitation. By increasing the concentration of $\mathrm{Eu}^{3+}$, the emission intensities of $\mathrm{Tb}^{3+}$ at $543 \mathrm{~nm}$ decrease remarkably while the emission intensity of $\mathrm{Eu}^{3+}$ at $626 \mathrm{~nm}$ initially increases and then reaches a maximum at $\mathrm{y}=0.10$, then decreases due to the concentration quenching. Therefore, we can speculate about the existence of energy transfer from $\mathrm{Tb}^{3+}$ to $\mathrm{Eu}^{3+}$ cations, such an energy transfer has also been observed in $\mathrm{Y}_{2} \mathrm{O}_{3}[11], \mathrm{Ca}_{8} \mathrm{MgLu}\left(\mathrm{PO}_{4}\right)_{7}$ [12]and $\mathrm{SrMg}_{2} \mathrm{La}_{2} \mathrm{~W}_{2} \mathrm{O}_{12}$ host materials[13].

To further certify the energy transfer from $\mathrm{Tb}^{3+}$ to $\mathrm{Eu}^{3+}$ ions in $\mathrm{Gd}_{2} \mathrm{O}_{2} \mathrm{CN}_{2}$ host matrix, the PL decay curves were measured (excited at $379 \mathrm{~nm}$ and monitored at 543nm) and the lifetimes of 


\section{ACCEPTED MANUSCRIPT}

different samples were calculated. Fig. 7 shows the decay curves of $\mathrm{Tb}^{3+}$ ions which can be well fitted to a double-exponential function as the following equation [14]:

$$
I=I_{0}+A_{1} \exp \left(-t / \tau_{1}\right)+\mathrm{A}_{2} \exp \left(-t / \tau_{2}\right)
$$

Where $\mathrm{I}$ is the luminescent intensity at the time of $\mathrm{t}$ and $\mathrm{I}_{0}$ is the luminescent intensity at the time of $0 ; A_{1}$ and $A_{2}$ are fitting parameters; $\tau_{1}$ and $\tau_{2}$ are rapid and slow lifetimes for exponential components, respectively. Based on these parameters, the average lifetime of $\mathrm{Tb}^{3+}$ ions with different $\mathrm{Eu}^{3+}$ concentration can be calculated by the following equation:

$$
\tau=\left(A_{1} \tau_{1}^{2}+A_{2} \tau_{2}^{2}\right) /\left(A_{1} \tau_{1}+A_{2} \tau_{2}\right)
$$

The effect of $\mathrm{Eu}^{3+}$ content on the calculated $\mathrm{Tb}^{3+}$ ions lifetimes was shown in the Fig. 7 inset, the decay lifetime of $\mathrm{Tb}^{3+}$ ions decrease with increasing $\mathrm{Eu}^{3+}$ concentration, which strongly supported the energy transfer from $\mathrm{Tb}^{3+}$ ions to $\mathrm{Eu}^{3+}$ ions.

Table 1 summarizes the CIE chromaticity coordinates of $\mathrm{Gd}_{1.85-\mathrm{y}} \mathrm{Tb}_{0.15} \mathrm{Eu}_{\mathrm{y}} \mathrm{O}_{2} \mathrm{CN}_{2}(0 \leq \mathrm{y} \leq 0.20)$ phosphors under the excitation at 379nm, Figure 8 also gives the CIE chromaticity coordinates, and it is interesting to notice that with the increasing of $\mathrm{Eu}^{3+}$ ions concentration, the CIE chromaticity coordinates shift from $(0.3134,0.5454)$ to $(0.5682,0.3322)$, the emitting color turned from green to red accordingly. The inset of Fig. 8 also shows the digital photos of $\mathrm{Gd}_{1.85} \mathrm{~Tb}_{0.15} \mathrm{O}_{2} \mathrm{CN}_{2}$ (a), $\mathrm{Gd}_{1.83} \mathrm{~Tb}_{0.15} \mathrm{Eu}_{0.02} \mathrm{O}_{2} \mathrm{CN}_{2}$ (b) and $\mathrm{Gd}_{1.70} \mathrm{~Tb}_{0.15} \mathrm{Eu}_{0.15} \mathrm{O}_{2} \mathrm{CN}_{2}$ (g) phosphors under excitation at 379nm light. With the development of chip technology, high-performance InGaN-based $380 \mathrm{~nm}$ UV LEDs are fabricated [15] and commercially available NUV InGdN LED

chip from 375 to $380 \mathrm{~nm}$ is more and more common. Therefore, $\mathrm{Eu}^{3+}, \mathrm{Tb}^{3+}$ co-doped $\mathrm{Gd}_{2} \mathrm{O}_{2} \mathrm{CN}_{2}$ phosphors may have potential applications for NUV LEDs.

\section{Conclusion}


In this paper, $\mathrm{Eu}^{3+}, \mathrm{Tb}^{3+}$ singly doped and $\mathrm{Eu}^{3+}-\mathrm{Tb}^{3+}$ co-doped $\mathrm{Gd}_{2} \mathrm{O}_{2} \mathrm{CN}_{2}$ phosphors were successfully prepared by classical solid-state reaction. The $\mathrm{Tb}^{3+}$ doped $\mathrm{Gd}_{2} \mathrm{O}_{2} \mathrm{CN}_{2}$ phosphors exhibit a characteristic green emission with the strong peak at 543nm. The optimized $\mathrm{Tb}^{3+}$ concentration of $\mathrm{Gd}_{2} \mathrm{O}_{2} \mathrm{CN}_{2}: \mathrm{Tb}^{3+}$ is 7.5 at. \%. When $\mathrm{Eu}^{3+}$ and $\mathrm{Tb}^{3+}$ were co-doped into $\mathrm{Gd}_{2} \mathrm{O}_{2} \mathrm{CN}_{2}$, an efficient energy transfer from $\mathrm{Tb}^{3+}$ to $\mathrm{Eu}^{3+}$ occurred and thus by only increasing the doping concentration of $\mathrm{Eu}^{3+}$, it becomes possible to tune the emission color from green to orange and then to red under the excitation at 379nm.

\section{Acknowledgement}

This project has been supported by the National Natural Science Foundation of China (No.51502091), and the Fundamental Research Funds for the Central Universities (WD1314055, WD1313009).

\section{References}

1 E. Sailynoja, M. Lastusaari, J. Holsa, P. Porcher, "Luminescence of a novel rare earth oxycompound $\mathrm{La}_{2} \mathrm{O}_{2} \mathrm{CN}_{2}$ :Eu ${ }^{3+}$," Journal of Luminescence.72-74 201-203(1997).

2 J. Holsä , R.-J. Lamminmäki , M. Lastusaari, P. Porcher, and E. Säilynoja, “Crystal field effect in $\mathrm{RE}$-doped lanthanum oxycyanamide, $\mathrm{La}_{2} \mathrm{O}_{2} \mathrm{CN}_{2}: \mathrm{RE}^{3+}\left(\mathrm{RE}=\mathrm{Pr}^{3+}\right.$ and $\left.\mathrm{Eu}^{3+}\right)$," J. Alloys Compd. 275-277, 402-406 (1998).

3 T. Takeda, N. Hatta, and S. Kikkawa, "Gel nitridation preparation and luminescence property of Eu-doped $\mathrm{RE}_{2} \mathrm{O}_{2} \mathrm{CN}_{2}$ (RE =La and Gd) phosphor,” Chem. Lett. 35, 988-989 (2006).

4 H.-J. Meyer, "Solid state metathesis reactions as a conceptual tool in the synthesis of new materials,” Dalton Transactions. 26, 5973-5982(2010).

5 T. Hang, Q. Liu, D. L. Mao, C. K. Chang, “Long lasting behavior of $\mathrm{Gd}_{2} \mathrm{O}_{2} \mathrm{~S}: \mathrm{Eu}^{3+}$ phosphor 


\section{ACCEPTED MANUSCRIPT}

synthesized by hydrothermal routine," Materials Chemistry and Physics. 107, 142-147(2008).

6 J. Sindlinger, J. Glaser, H. Bettentrup, T. Jüstel, and H.-J. Meyer, "Synthesis of $\mathrm{Y}_{2} \mathrm{O}_{2}\left(\mathrm{CN}_{2}\right)$ and luminescence properties of $\mathrm{Y}_{2} \mathrm{O}_{2}\left(\mathrm{CN}_{2}\right)$ : Eu,” Z. Anorg. Allg. Chem. 633, 1686-1690 (2007).

7 S. H. Yang, C. H. Yen, C. M. Lin, P. J. Chiang, "Energy transfer mechanism and luminescent properties of color tunable $\mathrm{LaPO}_{4}: \mathrm{Tm}, \mathrm{Eu}$ phosphor," Ceramics International.41, 82118215(2015).

8 T. Wang, X. H. Xu, D. C. Zhou, J. B. Qiu, X. Yu, "Tunable color emission in $\mathrm{K}_{3} \mathrm{Gd}\left(\mathrm{PO}_{4}\right)_{2}: \mathrm{Tb}^{3+}, \mathrm{Sm}^{3+}$ phosphor for n-UV white light emitting diodes,” Journal of rare earths. 33,361-365(2015).

9 L. T. Wang, S. L. Yuan, Y. X. Yang, F. Chevire, F. Tessier, and G. R. Chen, "Luminescent properties of novel red-emitting phosphor: $\mathrm{Gd}_{2} \mathrm{O}_{2} \mathrm{CN}_{2}: \mathrm{Eu}^{3+}$," Optical Materials Express. 5,2616-2624(2015).

10 G. Blasse, “Energy transfer in oxidic phosphors,” Phys. Lett. A, 28, 444-445 (1968).

11 Z. L. Liu, L. X. Yu, Q. Wang, Y. C. Tao, H. Yang, "Effect of Eu, Tb codoping on the luminescent properties of $\mathrm{Y}_{2} \mathrm{O}_{3}$ nanorods," Journal of Luminescence. 131,12-16(2011).

12 F. Y. Xie, J. H. Li, Z. Y. Dong, D. W. Wen, J. X. Shi, J. Yan, and M. M. Wu, "Energy transfer and luminescent properties of $\mathrm{Ca}_{8} \mathrm{MgLu}\left(\mathrm{PO}_{4}\right)_{7}: \mathrm{Tb}^{3+} / \mathrm{Eu}^{3+}$ as a green-to-red color tunable phosphor under NUV excitation,” RSC Advances. 5, 59830-59836(2015).

13 K. Pavani, J. S. Kumar, L. R. Moorthy, "Photoluminescence properties of $\mathrm{Tb}^{3+}$ and $\mathrm{Eu}^{3+}$ ions co-doped $\mathrm{SrMg}_{2} \mathrm{La}_{2} \mathrm{~W}_{2} \mathrm{O}_{12}$ phosphors for solid state lighting applications," Journal of Alloys and Compounds.586,722-729(2014).

14 Y. Q. Zhai, M. Wang, Q. Zhao, J. B. Yu, X. M. Li. Fabrication and luminescent properties of 


\section{ACCEPTED MANUSCRIPT}

$\mathrm{ZnWO}_{4}: \mathrm{Eu}^{3+}, \mathrm{Dy}^{3+}$ white light-emitting phosphors. Journal of luminescence, 2016, 172: 161-167.

15 S. C. Huang, D.-S. Wuu, P. Y. Wu, and S.-H. Chan, "Improved output power of 380nm InGaN-Based LEDs using a heavily Mg-Doped GaN Insertion layer technique,” IEEE Journal of Selected Topics in Quantum electronics. 15, 1132-1136(2009).

FIG. 1. XRD patterns of $\mathrm{Gd}_{1.9} \mathrm{Eu}_{0.1} \mathrm{O}_{2} \mathrm{CN}_{2}, \mathrm{Gd}_{1.75} \mathrm{~Tb}_{0.15} \mathrm{Eu}_{0.1} \mathrm{O}_{2} \mathrm{CN}_{2}$ and $\mathrm{Gd}_{1.85} \mathrm{~Tb}_{0.15} \mathrm{O}_{2} \mathrm{CN}_{2}$ (the standard data of $\mathrm{Gd}_{2} \mathrm{O}_{2} \mathrm{CN}_{2}$ (PDF\#49-1169) is shown as reference)

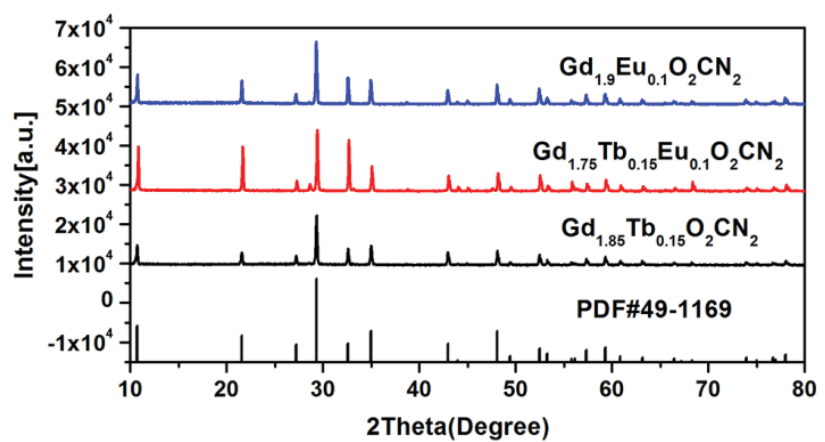

FIG. 2. FTIR spectra of $\mathrm{Gd}_{1.9} \mathrm{Eu}_{0.1} \mathrm{O}_{2} \mathrm{CN}_{2}, \mathrm{Gd}_{1.75} \mathrm{~Tb}_{0.15} \mathrm{Eu}_{0.1} \mathrm{O}_{2} \mathrm{CN}_{2}$ and $\mathrm{Gd}_{1.85} \mathrm{~Tb}_{0.15} \mathrm{O}_{2} \mathrm{CN}_{2}$ samples

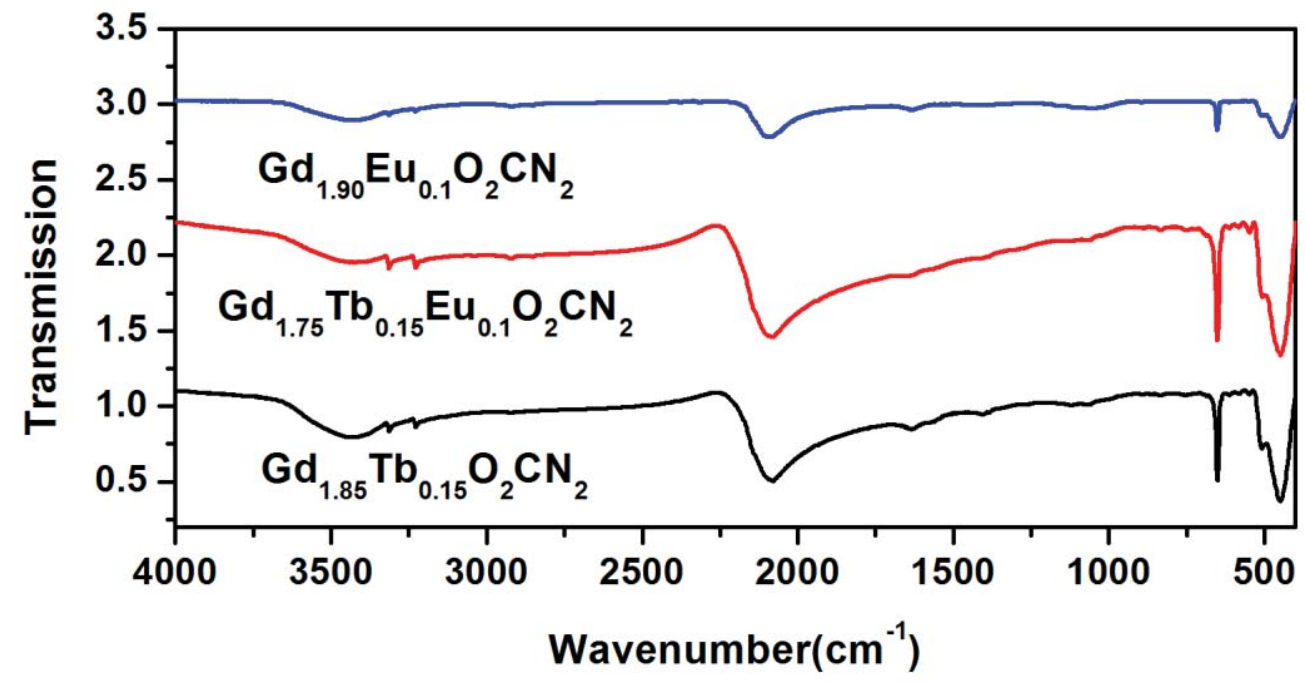


FIG. 3. Excitation (a) and Emission (b) spectra of the $\mathrm{Gd}_{1.85} \mathrm{~Tb}_{0.15} \mathrm{O}_{2} \mathrm{CN}_{2}$ sample. The right inset is the photograph image of the $\mathrm{Tb}^{3+}$-doped sample being excited by the $280 \mathrm{~nm}$ lights.

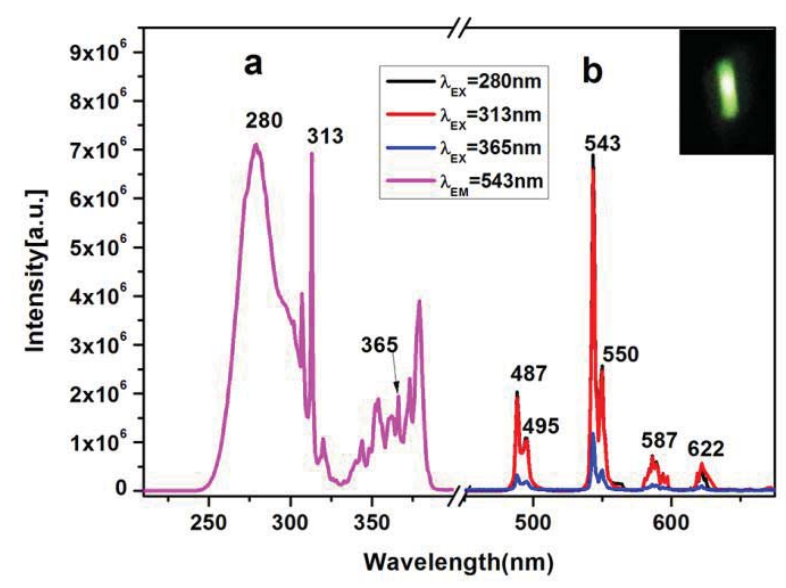

FIG. 4. Excitation (a) and emission (b) spectra of $\mathrm{Gd}_{2-\mathrm{x}} \mathrm{Tb}_{\mathrm{x}} \mathrm{O}_{2} \mathrm{CN}_{2}(\mathrm{x}=0.03,0.05,0.07,0.12,0.15$, 0.200) samples. The inset is the dependence of its PL intensity on the $\mathrm{Tb}^{3+}$ content in the $\mathrm{Gd}_{2} \mathrm{O}_{2} \mathrm{CN}_{2}$ matrix. 

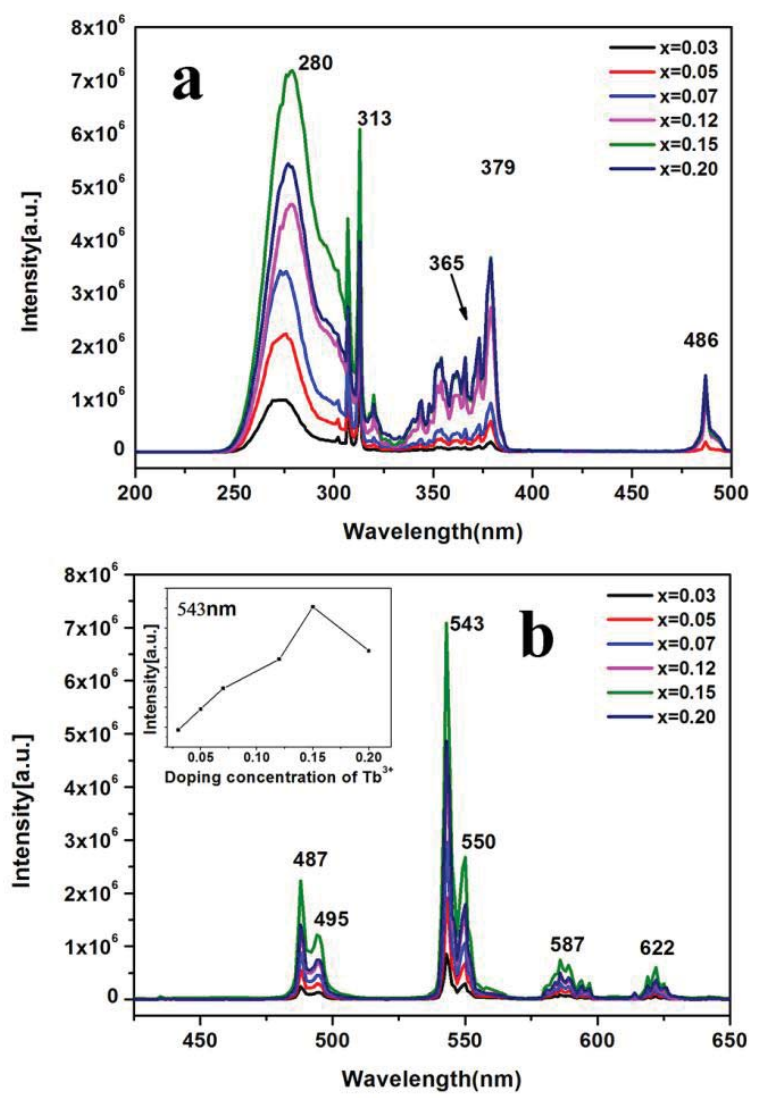

FIG. 5. Excitation and emission spectra of $\mathrm{Gd}_{1.90} \mathrm{Eu}_{0.10} \mathrm{O}_{2} \mathrm{CN}_{2}$ (a), $\mathrm{Gd}_{1.85} \mathrm{~Tb}_{0.15} \mathrm{O}_{2} \mathrm{CN}_{2}$ (b) and $\mathrm{Gd}_{1.83} \mathrm{Eu}_{0.02} \mathrm{~Tb}_{0.15} \mathrm{O}_{2} \mathrm{CN}_{2}$ (c)
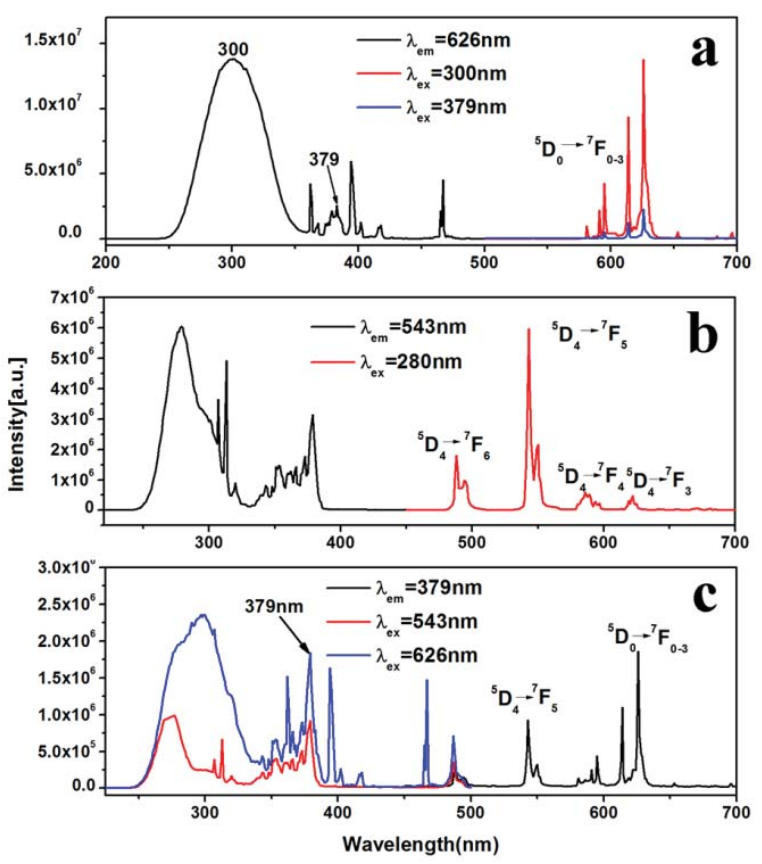
FIG. 6. Emission spectra of $\mathrm{Gd}_{1.85-\mathrm{y}} \mathrm{Tb}_{0.15} \mathrm{Eu}_{\mathrm{y}} \mathrm{O}_{2} \mathrm{CN}_{2}(\mathrm{y}=0,0.02,0.04,0.06,0.08,0.10,0.15)$ samples under the excitation wavelength of 379nm

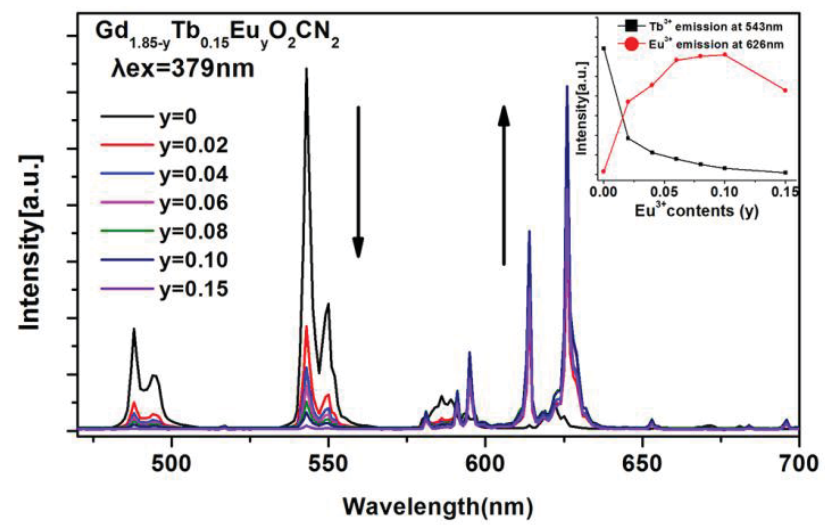

FIG. 7. Representative decay curves for the luminescence of $\mathrm{Tb}^{3+}$ in $\mathrm{Gd}_{1.85} \mathrm{~Tb}_{0.15} \mathrm{O}_{2} \mathrm{CN}_{2}$, $\mathrm{Gd}_{1.83} \mathrm{~Tb}_{0.15} \mathrm{Eu}_{0.02} \mathrm{O}_{2} \mathrm{CN}_{2}$ and $\mathrm{Gd}_{1.81} \mathrm{~Tb}_{0.15} \mathrm{Eu}_{0.04} \mathrm{O}_{2} \mathrm{CN}_{2}$. The inset shows the lifetime of $\mathrm{Tb}^{3+}$ as a function of $\mathrm{Eu}^{3+}$ concentration in $\mathrm{Gd}_{2} \mathrm{O}_{2} \mathrm{CN}_{2}$ host matrix (excited at $379 \mathrm{~nm}$ and monitored at 543 $\mathrm{nm})$.

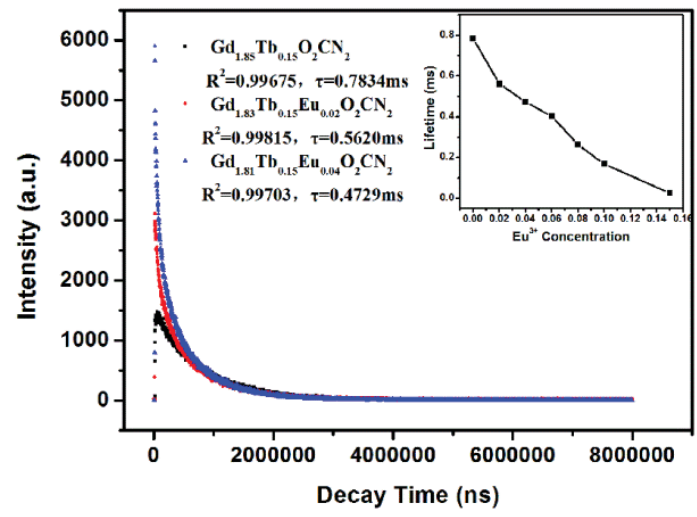


FIG. 8. CIE chromaticity coordinate digram of $\mathrm{Gd}_{1.85-\mathrm{y}} \mathrm{Tb}_{0.15} \mathrm{Eu}_{\mathrm{y}} \mathrm{O}_{2} \mathrm{CN}_{2}(\mathrm{y}=0,0.02,0.04,0.06$, $0.08,0.10,0.15$ ) samples under the excitation at $379 \mathrm{~nm}$ ( the inset shows the digital photos of the $\mathrm{Gd}_{1.85} \mathrm{~Tb}_{0.15} \mathrm{O}_{2} \mathrm{CN}_{2}$ (a), $\mathrm{Gd}_{1.83} \mathrm{~Tb}_{0.15} \mathrm{Eu}_{0.02} \mathrm{O}_{2} \mathrm{CN}_{2}$ (b) and $\mathrm{Gd}_{1.70} \mathrm{~Tb}_{0.15} \mathrm{Eu}_{0.15} \mathrm{O}_{2} \mathrm{CN}_{2}$ (g) phosphors under the excitation of 379nm light

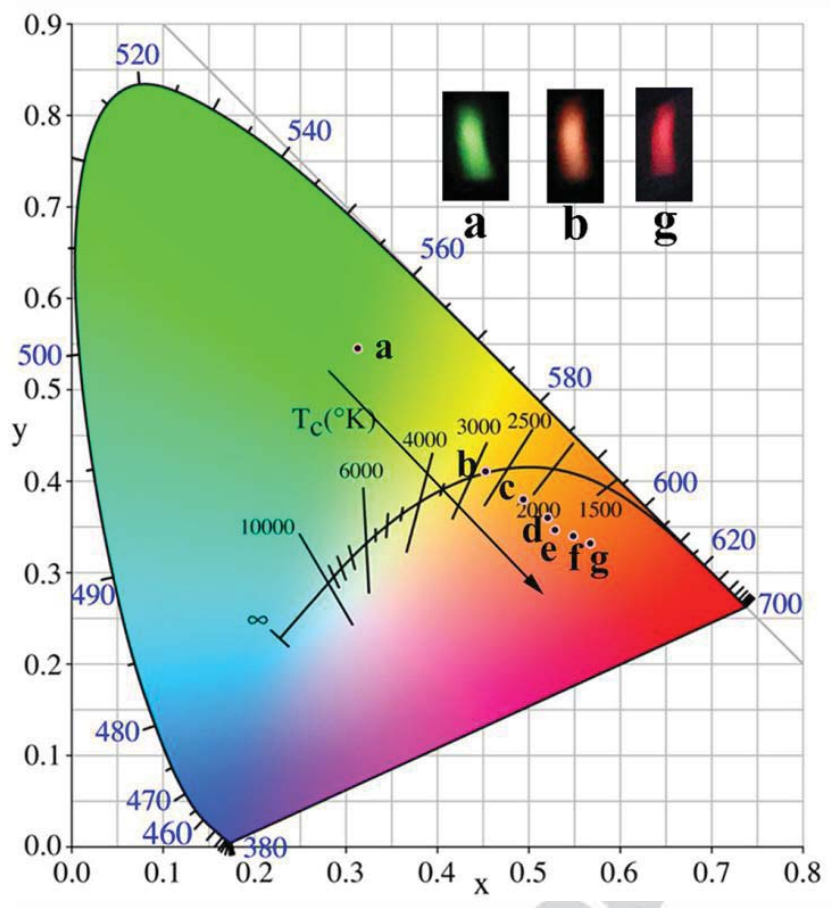

Table 1 CIE chromaticity coordinates for $\mathrm{Gd}_{1.85-\mathrm{y}} \mathrm{Tb}_{0.15} \mathrm{Eu}_{\mathrm{y}} \mathrm{O}_{2} \mathrm{CN}_{2}(\mathrm{y}=0,0.02,0.04,0.06,0.08,0.10$, 0.15) samples

\begin{tabular}{ccc}
\hline Sample no. & $\begin{array}{c}\text { Sample } \\
\text { composition(y) }\end{array}$ & CIE coordinates $(\mathrm{x}, \mathrm{y})$ \\
\hline $\mathrm{a}(\mathrm{T}-5)$ & $\mathrm{y}=0$ & $(0.3134,0.5454)$ \\
$\mathrm{b}($ ET- $)$ & $\mathrm{y}=0.02$ & $(0.4534,0.4112)$ \\
$\mathrm{c}($ ET-2) & $\mathrm{y}=0.04$ & $(0.4953,0.3794)$ \\
$\mathrm{d}($ ET-3) & $\mathrm{y}=0.06$ & $(0.5216,0.3596)$ \\
e (ET-4) & $\mathrm{y}=0.08$ & $(0.5289,0.3469)$ \\
$\mathrm{f}($ ET-5) & $\mathrm{y}=0.10$ & $(0.5493,0.3405)$ \\
\hline
\end{tabular}


